\author{
Liridon Dalipi \\ Faculty of Law, University "Kadri Zeka”, Gjilan \\ Arben Sahiti \\ Faculty of Economics, University "Kadri Zeka", Gjilan
}

\title{
ELECTION SILENCE AND MEDIA IN KOSOVO
}

\author{
UDK: 342.8 (497. 115) \\ Primljeno: rujan 2016. \\ Pregledni rad
}

Election process is a fundamental issue in a democratic society. Countries that manage to undergo fair process, based on values and principles, codes of conduct, and applicable laws are able to build up stable and trustworthy institutions. The role of media in this context is of paramount importance to ensure a transparent and accountable outcome. The issue of electoral silence has been a heated debate during the election process in Kosovo, given the loopholes in the existing laws and directives. The aim of this research is to analyse the electoral silence status as one of the specific segments of electoral processes, particularly in the case of Republic of Kosovo. Research has been carried out using secondary data from the existing literatures, applicable laws, cases, media, and other relevant bodies in Kosovo.

Key words: election silence; written and electronic media; election codes; election laws

\section{INTRODUCTION}

Political parties and other forms of organization and political union, at any time claim their best propaganda, in order to convince the electoral body to vote for them. In this context, they do not save the electoral silence to realize their goals. Mostly, in this segment, they realize their propagandistic goals through media including written media and electronic. There are codes, laws and other judicial acts that stipulate how those mediums should behave during election silence and also show the consequences if legal acts are violated during electoral silence.

Despite these legal acts that have sanctioned in principle the status of electoral silence, much remains to be done in this segment because it is not covered by codes, laws and other legal acts, the media status of external cable broadcasters operating in Kosovo, portals and social networks. Despite these legal acts that have sanctioned in principle the status of electoral silence, much remains to be done in this segment because it is not covered by codes, laws and other legal acts, status of external media cable broadcasters operating in Kosovo, portals and social networks. This is not a small challenge that must be overcome through normative acts. 


\section{ELECTION SILENCE}

The election campaign is defined by law or other legal acts from each state or country. It usually starts thirty (30) days before Election Day and ends 24 hours before the election. Election silence means that political parties, organizations and other forms of organization and political union are reserved to campaign on a specific period of time before the elections.

The aim of the election silence is that participants in elections, regardless whether they are active or passive create their discretionary obedience to decide whom to give the vote. Electoral silence period will usually start a day before the day of the elections, and it continues on Election Day, until the evening when polling stations are closed. ${ }^{1}$ According to the Electoral Code of Albania, in the period of electoral silence is not allowed any kind of election campaign through media outlets and rallies are banned, dissemination or other election activities elective subjects, ${ }^{2}$ such as:

- Prohibition on emphasis on party symbols

- Prohibition of exercising pressure on citizens

- Prohibition of citizens to convince voters to vote for their candidates

- Prohibition of surveys for parties and candidates participating in election

- Prohibition of early proclamation of election results

Law on Elections of the Republic of Kosovo, does not contain provisions to clarify the election silence, but it decisively sanctions the prohibited actions before voting process.

According to the law "Prohibited Actions Prior to Polling are as follows: Twenty-four hours before the opening of Polling Stations for the casting of the vote, and until their closing, political entities, their supporters or candidates, are prohibited from doing any of followings:

- Distributing or displaying the other way in any Polling Stations, or 100 meters within the same space, of any material for the purpose of influencing voters;

- Campaigning in anyway. ${ }^{3}$

Law on Elections in Kosovo, does not specify exactly electoral silence implying only restrictions before voting and prohibitions during the voting process. The presence of competent officials Election Day, the act of voting secrecy and security of the ballot box presents electoral silence process.

According to the Croatian election law article 26, paragraph 2, and twenty four (24) hours before Election Day voting and election campaigning is prohibited, evaluation of the election results, unofficial election results, publication of

1 Haxhiu, Sadik; Zgjedhjet, Sistemt Zgjedhore dhe Proceset Zgjedhore; botoi Ministria e Arsimit, Shkencës dhe Teknologjisë, 2013, Prishtinë, faqe 419

Kodi Zgjedhor i Republikës së Shqipërisë, Nr.10 019, datë 29.12.2008, neni 77, paragrafi 1,2

3 Ligji nr. 03/L-073 Për Zgjedhjet e Përgjithshme në Republikën e Kosovës; 15.06.2008, neni 36, paragrafi $1,2,3$ 
photographs in media statements and interviews of candidates or parties submitting the lists. ${ }^{4}$ While under Article 16, paragraph 10 of the Electoral Law of Bosnia and Herzegovina in the period from forty-eight (48) hours before the opening of the polling stations until the closing of polling stations will not publish results of public opinion polls about elections and voting.

\section{VIOLATION OF ELECTORAL SILENCE IN THE REPUBLIC OF KOSOVO}

One of the very significant forms of violation of electoral silence recently in Kosovo is breaking through internet messages and messages from cell phones. Activists of political parties through mobile phones urge voters to go to the polls and vote for their parties or candidates. This has occurred largely during the parliamentary elections in 2007, 2010 and 2014. The bodies that manage the election process can identify these cases as they are numerous and take appropriate legal action for violation of electoral silence. To succeed the electoral silence, bodies that administer the elections and entities participating in the elections shall denounce violators of electoral silence and impose upon them penalties in conformity with the electoral code or other legal acts in force.

\section{VIOLATION OF THE ELECTORAL SILENCE BY POLITICAL PARTIES AND MEDIA}

Political parties and other forms of organization and political union even though with the election law are required twenty four (24) hours ahead to begin the electoral silence, they still find the most varied forms to continue the campaign with other methods. Law on General Elections in Kosovo, Section 52.1 states: No person or media outlet shall broadcast or publish any material pertaining to campaign activity during the period commencing twenty-four hours before the opening of polling stations until the official close of polling stations ${ }^{5}$. In practice, senior government officials such as ministers, deputy ministers and other government representatives who had been the candidate to be elected, have campaigned in the election silence period. If during the election silence a certain Minister promotes a project that is important to the electorate such as: roads, sewerage, water or any other form of promotion, that is contributing to the state and its citizens, it means that we are dealing with violation of electoral silence.

\footnotetext{
${ }^{4}$ file:///C:/Users/Ëindoës/Doënloads/Zakon\%20o\%20izboru\%20zastupnika\%20u\%20Hrvatski\%20 sabor_procisceni\%20tekst.pdf klikuar me 2016-10-23

5 http://ëëë.assembly-kosova.org/common/docs/ligjet/2008_03-L073_al.pdf i klikuar per her te fundit me date 22 tetor 2016
} 
On the other hand, when a government representative expects different delegations and through the media presents certain successes for a certain Ministry which he/or she is leading, it is definitely a violation of electoral silence. Other cases of electoral silence are shown in practice, where in various TV and radio programs are invited heads of election headquarters to explain the preparations related to the electoral process, but considering the nature of programs (live programs), it has occurred in those programs very little discussion about the electoral process, where almost all the propaganda in the program is transferred to the programs of their political parties or individual candidates running for election. Electoral law stipulates electoral silence, the media are obliged to respect, even though the provisions of the law in question is not defined exactly what the ban on political parties and other entities participating in the elections during the electoral silence. These shortcomings in practice often cause problems in the content of silence.

In Kosovo's election law, the following specifications are lacking that:

a. Who from the representatives of the state and in what situation are entitled to appear before the public through the media?

b. Whether or not are allowed protocol news of governing institutions during the period of electoral silence?

c. Whether or not different inaugurations are allowed, especially of infrastructure from members of the government, who are also candidates in the elections?

In Kosovo, there is no publication that is conducted or broadcast of the results of public opinion research that has to do with the election campaign, including exit polls during the period that begins 24 hours before the official closing of polling stations and until the conclusion of the electoral process ${ }^{6}$. In application of Article 52.2 of the law on elections, there are appeared many problems in practice, since most servers of audio-visual media, while reporting do present the incidents that occur. Often in these cases the media claim to play the role of judicial bodies for which are not competent. Media reporting the conclusions that: NN supporters of the political party contesting the election, used force against XX party supporters.

The Independent Media Commission (IMC) is an independent body which is responsible for the regulation, management and supervision of the broadcasting frequency spectrum. Media service providers which are established and that editorial decisions are taken in the Republic of Kosovo as well as media service provider has its head office in the Republic of Kosovo but editorial decisions are taken within the EU or in other countries. ${ }^{7}$ So according to the provisions of the IMC, for the television programs that we receive from the region and Europe, through the cable platform, they are not subject to the jurisdiction of IMC, although they appear in the territory of Kosovo (such regulation is the practice of EU countries).

$\begin{array}{ll}6 & \text { Ibid } \\ 7 & \text { Ibid }\end{array}$ 
But the problem is that in Kosovo, the providers of audio-visual media from Albania have very high visibility and this element of the media market in Kosovo, it has not escaped the attention to Kosovo politicians, who on the day of election silence participate in TV programs in Albania.

According to the $\mathrm{IMC}^{8}$ research, receipt of television signals through cable system in the Republic of Kosovo is $49.2 \%$ and if you add to this the other platforms like the satellite which is $8.2 \%$, which lies mainly in rural areas, where they could not infiltrate the cable system or television via the internet (IPTV), of which lies $1.6 \%$, we note also that televisions in the region with over $50 \%$ of our population, could constitute violations of the election campaign, including election silence. These are contrary to the law on elections (Articles 52.1 and 52.2), and the media regulatory authority (IMC) can not take any action to prevent or to sanction these actions.

\section{Sanctions after violating the electoral silence}

IMC, on the December 15, 2010, took the sanctioning decision for fining of the service provider program Klan Kosova, since based on monitoring reports, has concluded that Klan Kosova has violated Article 52.1 of the Law on elections, where before official closure of polling stations, it has consistently shown the statements of representatives of various political parties who have participated in the elections. Although, Klan Kosova is fined for violating certain regulation and the violation in some cases were made consciously in order to have the highest visibility in the day of election, the fine imposed was not equal to the damage made to other media that have respected the silence. The action made by Klan Kosova should serve as an important case to put in motion the respective institutions to review once again the attention devoted to the legislation of the electoral law that defines silence.

\section{a. Portals}

The biggest concern recently is the large number of portals, which obviously are taking over the place of daily newspapers, and according to recent statistics, about seventeen percent of the population are informed through the internet and only two percent through newspapers9. The percentage of media that are subject to legal regulations every day more and more are falling. This is made for the great reasons since portals in Kosovo are not regulated by any act or media regulator, and do not use its regulatory system as is the case with printed media. Apart from the above mentioned concerns, portals with comments that their readers can give which are indeed public, can do negative campaign against non-preferred candidates, greatly this undermines the electoral process, both in the information and during election silence.

8 http://www.kpm-ks.org/materiale/dokument/1327504207.3477.pdf, i klikuar për herë të fundit më 23 tetor 2016

9 http://rajonipress.com/shfleto-artikujt.php?id=8608, klikuar per herë të fundit me datë 27 mars 2013 


\section{b. Social networks}

Another phenomenon that is doing great competition to media are social networks, which occasionally with the help of portals, within a few minutes distribute very important material and information.

According to some statistics, in Kosovo there are over 850 thousand of internet users, representing about 45 percent of the population ${ }^{10}$. Given that the average age of the population is very young and younger people largely use social networks, especially those such as Twitter and Facebook, here we see how easy it is during election silence, to deal with propaganda policy, which does not have any legal act or institution that can stop or fix. So, in these situations we see that the worse suffering are entities participating in elections and media providers of audio and audio-visual, which must respect the laws in force.

\section{CONCLUSIONS AND RECOMMENDATIONS}

The media play an irreplaceable role in building free and democratic societies and to the various processes that society is going through. It is the backbone of information, communication holder between the government and the people, influencer and public opinion maker, motivation and inspiration of modern trends and global developments, melting of different cultures, influencer of great idea of globalization and intercontinental integration. Media pluralism is an indispensable element of democracy, since in this way the diversity of thoughts and opinions is created. But the information that the media has as a mission should be based on certain principles and legal standpoint, which should be respected by the media. Kosovo Elections Law should be amended, in particular by specifying the electoral silence.

Based on the recent fields in Kosovo, we have noticed that they should pay special attention to the amendment of the legislation, this should be done in such cases:

- To supplement existing legislation and determine the details of which have to do with the campaign and election silence;

- To sanction by law and other legal acts that on how other electronic media, portals and social media be sanctioned if election silence is violated.

- To specify that during the campaign of silence period, cable operators, not to display their programs which directly or indirectly are related to elections.

The main issues presented in this study, are the media of countries in the region that come to the viewer through cable operators (network operators), and which can

10 Ibid 
not be adjusted for the content of their local institutions. Here should be reviewed the possibility of agreements between the regulators of the region, where according to memorandums of understanding and through legal acts, the legislation should be regulated. Amendments to the electoral laws and codes and memoranda of understanding between cable operators in the region will significantly reduce the violation of electoral silence in Kosovo, which in recent years has caused irreparable damage to the electoral body.

\section{REFERENCES:}

1. Guy S. Godëin Gill; Zgjedhjet e drejta dhe të lira - e Drejta Ndërkombëtare dhe Praktika; Inter Parlamentary Union 1994, Gjenevë

2. Guy S. Godëin Gill; Codes of Conduct for Elections, Inter Parlamentary Union 1998, Gjenevë

3. Haxhiu Sadik; Zgjedhjet, Sistemet Zgjedhore dhe Proceset Zgjedhore, botoi Ministria e Arsimit, Shkencës dhe Teknologjisë, 2013 Prishtinë

4. Raport i botuar ne 2009: OSI/EU monitoring and advocacy Program, 2009, Open society institute, fondation media program, Televizioni në evropë, rregullativa, politika dhe pavarësia

\section{Web dokumets:}

1. http://www.etcgraz.at/typo3/fileadmin/user_upload/ETCHauptseite/manual/ versionen/albanian/express_media/express_media.pdf

2. Raporti i monitorimit i publikuar nga KIPRED, i monitoruar nga Demokracia në Veprim, Prishtinë, mars 2010) faqe 10, linku ku mund te gjindet raporti:

3. file://C:/Users/Windows/Doënloads/Zakon\%20o\%20izboru\%20zastupnika\%20 u\%20Hrvatski\%20sabo procisceni\%20tekst.pdf klikuar me 2016-10-23

4. http://izbori.ba/Documents/documents/ZAKONI/Izborni_zakon_PRECISCENI_ TEKST-bos.pdf

5. http://www.kipred.org/advCms/?id=50,146,146,146,a,,28\&searchFor=\&searchIn

6. http://www.osce.org/sq/albania/159511?doënload=true

7. http://www.kpm-ks.org/?faqe=9\&gjuha=1\&mod=kontakt,

8. http://www.kpm-ks.org/materiale/dokument/1327504207.3477.pdf

9. http://www.assembly-kosova.org/common/docs/ligjet/2008_03-L073_al.pdf

10. http://www.assembly-kosova.org/common/docs/ligjet/Ligji\%20per\%20KPM.pdf,

11. http://rajonipress.com/shfleto-artikujt.php?id=8608 


\section{IZBORNA ŠUTNJA I MEDIJI NA KOSOVU}

Izborni postupak je od temeljnog značaja za demokratsko društvo. Zemlje koje su u stanju osigurati pošteni postupak koji se temelji na vrijednostima i načelima, pravilima ponašanja i primjenjivim zakonima u stanju su izgraditi stabilne i pouzdane institucije. Uloga medija u ovom kontekstu od velike je važnosti radi osiguranja transparentnog i odgovornog ishoda. Zahvaljujući nedostacima u postojećim propisima, pitanje izborne šutnje postalo je goruće pitanje na Kosovu. Cilj ovog osvrta jest analiza statusa izborne šutnje kao specifičnog segmenta izbornog postupka posebno u slučaju Republike Kosova. Istraživanje je napravljeno korištenjem sekundarnih podataka iz postojeće literature, zakonskih propisa, sudskih odluka, sredstava informiranja i drugih relevantnih tijela na Kosovu.

Ključne riječi: izborna šutnja, pisani i elektronski mediji, izborno zakonodavstvo 